\section{Desain Indutri Sebagai Karya Yang Dilindungi (HAKI) \\ Oleh:}

\section{Azhari AR. ${ }^{1}$ Gema Rahmadani ${ }^{2}$}

\section{Abstract}

A designer has a copyright on the results of his creativity in the form of a blueprint and has the exclusive right to make the artwork into three or two dimensions. The industrial design law is directed at protecting mass-produced goods. People prefer protection with the right to industrial design, which is only protected for 10 years. This is because a design is very easy and can be imitated quickly by the general public. When it is protected by copyright, it becomes ineffective and wasteful. Copyright does not protect mass products.

Keywords: Design, Industry, Work, Intellectual Property Rights

\begin{abstract}
Abstrak
Seorang pendesain mempunyai hak cipta atas hasil kreativitasnya yang berupa cetak biru dan mempunyai hak eksklusif untuk membuat karya seni itu menjadi tiga atau dua dimensi. Undang-undang desain industri diarahkan untuk melindungi barang-barang yang diproduk secara masal. Orang lebih memilih perlindungan dengan hak atas desain industri, yang hanya dilindungi selama 10 tahun. Hal ini disebabkan suatu desain sangat mudah dan cepat ditiru oleh masyarakat umum. Bila dilindungi dengan hak cipta, menjadi tidak efektif dan mubasir. Hak cipta tidak melindungi produk masal.
\end{abstract}

Kata Kunci : Desain, Indutri, Karya, Haki

\footnotetext{
${ }^{1}$ Dosen Tetap Fakultas Hukum UISU

${ }^{2}$ Alumni Magister Ilmu Hukum FH-UISU
}

\section{A. Pengertian Desain Industri}

Desain industri (Industrial design) adalah seni terapan di mana estetika dan usability (kemudahan dalam menggunakan suatu barang) suatu barang disempurnakan. Desain industri menghasilkan kreasi tentang bentuk, konfigurasi, atau komposisi garis atau warna atau garis dan warna atau gabungannya, yang berbentuk 3atau 2 dimensi, yang memberi kesan estetis, dapat dipakai untuk menghasilkan produk, barang, komoditas industri atau kerajinan tangan. Sebuah karya desain dianggap sebagai kekayaan intelektual karena merupakan hasil buah pikiran dan kreatifitas dari pendesainnya, sehingga dilindungi hak ciptanya oleh pemerintah melalui Undang-Undang No. 31 tahun 2000 tentang Desain Industri. Kriteria desain industri adalah baru dan tidak melanggar agama, peraturan perundangan, susila, dan ketertiban umum. Jangka waktu perlindungan untuk desain industri adalah 10 tahun terhitung sejak tanggal penerimaan permohonan Desain Industri ke Kantor Ditjen Hak Kekayaan Intelektual.

Desain Industri adalah cabang HKI yang melindungi penampakan luar suatu produk. Sebelum perjanjian TRIPS lahir, desain industri dilindungi oleh Undang-Undang Hak Cipta. Namun karena perkembangan desain yang sangat pesat, maka perlu dibuatkan UU Khusus yang mengatur tentang desain industri.

Desain industri pada dasarnya suatu proses penciptaan dan penemuan yang tidak terpisah dari segi - segi produk mencakup perpaduan antara faktor - faktor pendukung dan faktor - faktor yang (acapkali) bertentangan ke 
Media Komunikasi dan Informasi Hukum dan Masyarakat

dalam gubahan konsep tiga dimensional serta realitas material yang bias direproduksi dengan peralatan mekanik. ${ }^{3}$ Istilah desain industri (industrial design) diatur dalam Pasal 25 dan Pasal 26 TRIP's Agreement. Dalam UndangUndang Nomor 5 tahun 1984 tentang perindustrian, istilah yang dipakai adalah desain produk industri. Sedangkan istilah industrial design sering digunakan oleh Masyarakat Eropa dan Jepang. ${ }^{4}$

\section{Menurut Bruce}

Archer pengertian

desain adalah salah satu bentuk kebutuhan badani dan rohani yang menjabarkan melalui berbagai bidang pengalaman, keahlian, dan pengetahuan pada apresiasi dan adaptasi terhadap sekelilingnya terutama yang berhubungan dengan bentuk, komposisi, arti, nilai dan berbgai tujuan benda buatan manusia. ${ }^{5}$. Desain adalah bentuk karya seseorang hasil curahan kemampuan intelektualnya, yang terwujud tidak hanya dalam bentuk karya diatas kertas saja melainkan sudah terbentuk dalam wujud nyata suatu benda yang memiliki nilai manfaat bagi kehidupan manusia. $^{6}$

Secara Yuridis dapat kita lihat pengertian desain industri di dalam Pasal 1 angka (1) Undang - Undang No. 31 Tahun 2000, dijelaskan bahwa adalah "suatu kreasi tentang bentuk, konfigurasi, atau komposisi garis atau warna, atau garis, dan warna, atau gabungan daripadanya yang berbentuk tiga dimensi yang mengandung nilaiestetika dan

${ }^{3}$ John Heskett, Desain Indusri, Terjemahan Chandra Johan, Rajawali, Jakarta, 1986, hIm 5.

4 Suyud Margono dan Amir Angkasa, Komersialisasi Aset Intelektual (Aspek Hukum Bisnis), Grasindo, Jakarta, 2002, hlm 36

${ }^{5}$ Rizky A. Adiwilaga, Impelmantasi UU. No. 31 Tahun 2000, Disajikan dalam Pelatihan HAKI, LKBH UII, Yogyakarta, 2001, hlm 3.

6 Muhammad Djumhamna, Aspek - Aspek Hukum Desain Industri di Indonesia, Citra Aditya Bakti Bandung, 1999 hlm 1. dapat diwujudkan dalam pola tiga dimensi atau dua dimensi serta dapat dipakai untuk menghasilkan suatu produk barang, atau komoditi dan kerajinan tangan (vide Pasal 1 angka 1 Rancangan Undang - Undang Desain Industri)".

David Brainbridge dalam bukunya Computer and The Laws memberikan penjelasan arti desain. Menurutnya desain merupakan aspek-aspek dari atau fitur-fitur yang terdapat pada suatu barang. Sementara itu Jeremy Phillips dan Alison Firth menyatakan bahwa desain mencakup segala aspek tentang bentuk atau konfigurasi susunan baik internal maupun eksternal baik yang merupakan bagian maupun keseluruhan dari sebuah benda. Dari pendapat ini dapat dikemukakan bahwa desain merupakan suatu aspek-aspek yang mencakup pada bentuk dan konfigurasi. ${ }^{7}$

Dari batasan pengertian desain industri di atas terdapat beberapa unsur dari desain industri, sebagai berikut:

1. Kreasi yang dilindungi oleh UU Desain Industri dapat berbentuk tiga dimensi (bentuk dan konfigurasi) serta dua dimensi (komposisi garis atau warna).

2. Kreasi tersebut memberikan kesan estetis.

3. Kreasi tersebut dapat dipakai untuk menghasilkan suatu produk, barang, komoditas industri, atau kerajinan tangan.

Sejak Indonesia meratifikasikan perjanjian WTO dan TRIPs yang merupakan lampirannya, maka Indonesia harus tunduk kepada aturan yang bersifat global tersebut Selain itu pengertian desain industri yang diberikan UU Desain Industri tidak jauh berbeda

7 http://www. Iprcentre.org/artikel, 28 Juli 2016,13.30 WIB 
Media Komunikasi dan Informasi Hukum dan Masyarakat

dengan perngertian yang disusun dalam perundang - undangan negara lain: ${ }^{8}$

\section{Sejarah Desain Industri}

Pengaturan tentang Desain Industri dikenal pada abad ke-18 terutama di Inggris karena adanya Revolusi Industri. Desain Industri awalnya berkembang pada sektor tekstil dan kerajinan tangan yang dibuat secara massal. UU pertama yang mengatur mengenai Desain Industri adalah "The designing and printing of linens, cotton, calicoes and muslin act"sekitar tahun 1787. Pada saat ini Desain Industri hanya dalam bentuk 2 Dimensi. Sedangkan Desain Industri dalam bentuk 3 (tiga) Dimensi mulai diatur melalui Sculpture Copyright Act 1798 pengaturannya masih sederhana hanya meliputi model manusia dan binatang. Lalu pada tanggal 20 Maret 1883 The Paris Convention for the Protection of Industrial Property (Paris Convention). Amanat pada pasal 5 Paris Convention menyatakan bahwa Desain Industri harus dilindungi di semua negara anggota Paris Convention?.

Perlindungan desain memberikan hak monopoli kepada pemilik desain atas bentuk, konfigurasi, pola atau ornamentasi tertentu dari sebuah desain. Dengan demikian, hukum desain hanya melindungi penampilan bentuk terluar dari suatu produk. Undang-Undang Desain Industri tidak melindungi aspek fungsional dari sebuah desain, seperti cara pembuatan produk, cara kerja, atau aspek keselamatannya. Pembuatan, peng-operasian dan ciri-ciri barang tertentu dilindungi oleh hukum paten.

\footnotetext{
8 Rachmadi Usman, Hukum Hak Atas Kekayaan Intelektual Perlindungan dan Dimensi Hukumnya di Indonesia, Bandung, 2003 hlm 425. ${ }^{9}$ https://id.wikipedia.org/wiki/Desain_industri
}

\section{B. Tata Cara Perolehan Desain Industri}

Hak desain industri tidak serta langsung didapatkan oleh pemiliknya, dan tidak serta merta melekat pada si pendesain, untuk mendapatkan hak tersebut seorang pendesain harus terlebih dahulu mengajukan permohonan pendaftaran secara tertulis kepada Direktorat Jendral Hak Kekayaan Intelektual dengan membayar biaya.

Sebagaimana yang telah disebutkan diatas bahwa tata cara perolehan hak atas desain industri atas dasar pemohonan pendaftaran, maka permohonan pendaftaran terhadap desain tersebut harus memuat:

1. Tanggal, bukan, dan tahun surat pemohon;

2. Nama, alamat lengkap, dan kewarganegaraan Pendesain;

3. Nama, alamat lengkap, dan kewarganegaraan Pemohon;

4. Nama, dan alamat lengkap Kuasa apabila Pemohonan diajukan melalui Kuasa; dan

5. Nama Negara dan tanggal penerimaan permohonan yang pertama kali, dalam hal Permohonan diajukan dengan Hak Prioritas (Pasal 11 ayat (1), ayat (2), ayat (3) UU Desain Industri.

Permohonan pendaftaran Desain Industri harus dilampiri dengan:

1. Contoh fisik atau gambar atau foto dan uraian dari Desain Industri yang dimohonkan pendaftarannya;

2. Surat kuasa Khusus dalam hal permohonan diajukan melalui kuasa;

3. Surat pernyataan bahwa Desain Industri yang dimohonkan pendaftarannya adalah milik Pemohon atau milik Pendesain. 
Media Komunikasi dan Informasi Hukum dan Masyarakat

Permohonan pendaftaran desain industri yang diajukan akan dinyatakan diterima pada saat tanggal diterimanya permohonan dengan catatan si pemohon sudah mengisi formulir permohonan dengan melampirkan contoh fisik atau gambar atau foto dan uraian dari desain industri yang dimohonkan perndaftarannya dan juga membayar sejumlah biaya permohonan sebagaimana dimaksud dalam Pasal 11 ayat (1). Pihak Dirjen HAKI akan memberitahukan kepada pemohon atau kuasanya secara tertulis jika persyaratan belum lengkap dan permohonan tersebut dianggap ditarik kembali, terkecuali biaya yang telah dikeluarkan. Pengajuan permohonan ini dapat ditarik kembali atas dasar inisiatif sendiri dari si pemohon dengan cara melakukan permohonan penarikan secara tertulis yang diajukan pada Dirjen HAKI.

Apabila permohanan diajukan secara bersama sama oleh lebih dari satu Pemohon, permohonan tersebut ditandatangani oleh satu pemohon dengan melampirkan persetujuan tertulis dari pemohon lainnnya. Apabila permohonan diajukan oleh bukan pendesain, permohonan harus disertai pernyataan yang dilengkapi dengan bukti yang cukup bahwa pemohon berhak atas Desain Industri yang bersangkutan (Pasal 11 ayat (4), ayat (5), ayat (6) UU Desain Industri).

Setiap permohonan hanya dapat diajukan untuk satu Desain Industri, atau beberapa Desain Industri yang merupakan satu kesatuan Desain Industri atau memiliki kelas yang sama (Pasal 13 UU Desain Industri). Yang diamksud dengan satu Desain Industri adalah satuan lepas Desain Industri, misalnya satu set cangkir dan teko adalah juga satu Desain Industri. Sedangkan yang dimaksud dengan "kelas" adalah kelas sebagaimana diatur dalam klasifikasi internasional tentang Desain Industri dari Konvensi Locarno. ${ }^{10}$

Pemohon yang bertempat tinggal di luar wilayah Negara Republik Indonesia harus mengajukan permohonan melalui kuasa. Kuasa tersebut adalah konsultan yang terdaftar di Direktorat Jendral Hak Kekayaan Intelektual. Pemohon tersebut harus menyatakan dan memilh domisili hukumnya di Indonesia (Pasal 14 UU Desain Industri). Domisili hukum yang dipilih itu biasanya adalah domisili konsultan sebagai kuasanya yang ditunjuk untuk mengurus pendaftaran Desain Industri miliknya.

Permohonan menggunakan hak prioritas harus diajukan dalam waktu paling lama enam bulan terhitung sejak tanggal penerimaan permohonan yang pertama kali diterima di Negara lain yang merupakan anggota Konvensi Paris atau anggota Organisasi Perdagangan Dunia (Pasal 16 ayat (1)). Permohonan dengan hak prioritas tersebut wajib dilengkapi dengan dokumen prioritas, yang disahkan oleh kantor yang menyelenggarakan pendaftaran Desain Industri, disertai terjemahannya dalam bahasa Indonesia, dalam waktu paling lama tiga bulan terhitung setelah berakhirnya jangka waktu pengajuan permohonan dengan hak prioritas Pasal 16 ayat (2) UU Desain Industri. Jika syarat tersebut tidak dipenuhi, maka permohonan tersebut dianggap diajukan tanpa menggunakan Hak prioritas. Hak prioritas adalah hak pemohon untuk memperolah pengkuan bahwa tanggal penerimaan permohonan yang diajukan di Indonesia sama

${ }^{10}$ Budi Agus Riswandi dan M. Syamsudin, Hak Kekayaan Intelektual dan Budaya Hukum, Ctk Pertama, Raja Grafindo Persada, Jakarta, 2004 hlm 55 
Media Komunikasi dan Informasi Hukum dan Masyarakat

dengan tanggal penerimaan permohonan yang diajukan di Negara asal. Dengan demikian dalma jangka waktu enam bulan terhitung dari tanggal pengajuannnya di luar negeri, ia dapat mengajukan prioritas di Indonesia.

Selain salinan surat permohonan yang telah disebutkan diatas, Direktorat Jendral Hak Kekayaan Intelektual dapat meminta agar permohonan dengan menggunakan hak prioritas dilengkapi pula dengan:

1. Salinan lengkap Hak Desain Industri yang telah diberikan sehubungan dengan pendaftaran yang pertama kali diajukan di Negara lain.

2. Salinan sah dokumen lain yang diperlukan untuk mempermudah penilaian bahwa Desain Industri yang menyatakan tanggal penerimaan adalah tanggal diterimanya permohonan dengan syarat Pemohon telah:

1. Mengisi formulir permohonan;

2. Melampirkan contoh fisik atau gambar atau foto dan uraian dari desain industri yang dimohonkan pendaftarannya;

3. Membayar biaya permohonan yang besar jumlahnya ditetapkan oelh pemerintah.

Persyaratan yang dicantumkan dalam Pasal 18 UU Desain Industri merupakan syarat minimal yang harus dipenuhi untuk mempermudah pemohon mendapatkan tanggal penerimaan permohonan. Tanggal penerimaan tersebut penting untuk menentukan saat mulai berlakunya jangka waktu perlindungan atas desain industri tersebut.

Jika terdapat kekurangan dalam pemenuhan syarat-syarat dan kelengkapan permohoanan pendaftaran desain menurut Pasal 19 UU Desain Industri, Direktorat Jendral HAKI memberitahukan kepada pemohon atau kuasanya agar kekurangan tersebut dipenuhi dalam waktu tiga bulan terhitung sejak tanggal pengiriman surat pemberitahuan kekurangan tersebut. Jangka waktu ini dapat diperpanjang paling lama satu bulan atas permintaan pemohon.dalam jangka tenggang waktu 3 atau 4 bulan tersebut, pemohon diharapkan dapat melengkapi kekurangan persyaratan dan kelengkapan yang disyaratkan dalamk permohonan pendaftaran hak desain industri, yang dihitung sejak tanggal pengiriman pemberitahuan oleh pemohon.

Selanjutnya dalam Pasal 20 UU Desain Industri, apabila kekurangan sebagaimana dimaksud dalam Pasal 19 ayat (1) tidak dipenuhi, maka Direktorat Jendral HAKI memberitahukan secara tertulis kepada pemohon atau kuasanya bahwa permohonannya dianggap ditarik kembali.

\section{Subjek Hak Desain Industri}

Subjek hukum desain industri adalah Pendesain, yaitu orang yang menghasilkan rancangan desain industri. Disamping itu, mereka yang menerima hak desain industri dari Pendesain juga dianggap sebagi subjek hak desain industri sebagaimana yang diatur daam Pasal 6 dan Pasal 7 UU Desain Industri.

Pihak-pihak yang dapat diberi hak untuk memperoleh hak atas desain indusri adalah: ${ }^{11}$

1. Pendesain atau yang menerima hak tersebut dari pendesain

2. Dalam hal Pendesain terdiri atas orang secara bersama, Hak Desain Industri diberikan kepada mereka secara bersama, kecuali jika diperjanjikan lain.

3. Jika suatu Desain Industri dibuat dalam hubungan dinas dengan pihak lain dalam lingkungan pekerjaannya, Pemegang Hak Desain Indsutri adalah pihak yang dan / atau dalam dinasnya Desain Industri itu dikerjakan, kecuali ada perjanjian lain antara kedua pihak dengan tidak mengurangi hak

${ }^{11}$ H. OK. Saidin, Aspek Hukum........op.cit. hlm 472 
Media Komunikasi dan Informasi Hukum dan Masyarakat

Pendesain apabila penggunaan Desain Industri itu diperluas sampai keluar hubungan dinas.

4. Ketentuan sebagaimana dimaksud dalam butir 1 berlaku pula bagi Desain Industri yang dibuat orang lain berdasarkan pesanan yang berlaku dalam hubungan dinas.

5. Jika suatu Desain Industri dibuat dalam hubungan kerja atau berdasarkan pesanan, orang yang membuat Desain Industri itu dianggap sebagai Pendesain dan Pemegang hak Desain Industri, kecuali jika diperjanjikan lain antara kedua pihak.

Dengan didaftarnya desain industri, hak yang diberikan kepada Pemegang Hak Desain Industri adalah hak ekslusif, yakni hak untuk melaksanakan Hak Desain Industri yang dimilikinya dan untuk melarang orang lain tana persetujuannya membuat, memakai, menjual, mengimpor, mengekspor dan / atau mengedarkan barang yang diberi Hak Desain Industri. Hak ini diberikan kepada pemegang hak desain industri dalam jangka waktu 10 tahun, dengan demikian pihak lain dilarang melaksanakan hak desain industri tersebut tanpa persetujuan pemegangnya kecuali pemakaian tersebut untuk kepentingan penelitian dan pendidikan sepanjang tidak merugikan kepentingan yang wajar dari pemegang Hak Desain Industri.

Kepentingan yang wajar adalah penggunaan untuk kepentingan pendidikan dan penelitian itu secara umum tidak termasuk dalam penggunaan hak desain industri. Misalnya, dalam pendidikan, kepentingan yang wajar dari Pendesain akan dirugikan apabila desain industri tersebut digunakan untuk seluruh lembaga pendidikan yang ada di kota tersebut.
Kriteria kepentingan tidak semata - mata diukur dari ada tidaknya unsur komersial, tetapi juga dari kuantitas penggunaannya. ${ }^{12}$

\section{Jangka Waktu Perlindungan Desain Industri}

Perlindungan hukum terhadap desain industri seolah tenggelam dalam hingar bingar kampanye anti pembajakan. Bagi kebanyakan orang istilah desain industri masih asing. Terbitnya UU mengenai Desain Industri memang tergolong baru - UU Nomor 31 Tahun 2000 yang berlaku sejak 20 Desember 2000. Pendaftarannya sendiri baru dimulai pada 16 Juni 2001. Tak heran, bila desain industri kalah beken dibandingkan Hak Cipta, Paten atau Merek. Padahal desain bagi masyarakat menjadi indikator akan nilai sebuah produk. Lihat saja, bagaimana desain telepon selular, mobil, motor, produk elektronik atau produk lain berubah demikian cepat. Dengan desain yang semakin menarik maka nilai sebuah produk ikut terdongkrak. Namun, ironisnya desain yang di daftar masih sangat sedikit dibandingkan begitu banyak jumlah produk yang dikeluarkan dalam industri.

Direktur Hak Cipta, Desain Industri, Desain Tata Letak Sirkuit Terpadu dan Rahasia Dagang Departemen Kehakiman dan HAM, Emawati Junus mengakui besarnya ketidaktahuan masyarakat terhadap perlindungan desain industri. Saat ini, pendaftaran terhadap desain industri yang masuk baru 8000 aplikasi dan di antaranya hanya 49 aplikasi berasal dari Usaha Kecil dan Menengah (UKM). Statistik pemohon dari luar negeri 14 persen dan 86 persen berasal dari dalam negeri. "Hak Cipta memang lebih dikenal

12 Rachmadi Usman, op.cit...,hlm 435 
Media Komunikasi dan Informasi Hukum dan Masyarakat

daripada desain industri. Bagi masyarakat desain industri masih sangat baru," ujarnya.

Jika Hak Cipta atau Merek adalah perlindungan terhadap produk tersebut maka desain industri adalah perlindungan terhadap penampakan suatu produk. Jadi perlindungan lebih pada bentuk kreasi penampakan dan konfigurasi yang tampak pada suatu produk bukan perlindunga terhadap produk tersebut. ${ }^{13}$

Perlindungan Hak Cipta bersifat otomatis saat ekspresi nyata terwujud dan tanpa pendaftaran (deklaratif). Sedangkan perlindungan Desain Industri diberikan berdasarkan pendaftaran terhadap desain yang baru (konstitutif). Karya cipta merupakan sebuah karya master piece dan tidak diproduksi secara massal sedangkan Desain Industri diproduksi massal. ${ }^{14}$

Seperti kita ketahui persyaratan pendaftaran merupakan hal yang paling penting dalam Desain Industri dan merupakan kepentingan pemegang hak desain industri, yang pada prinsipnya memberi perlindungan.

Sistem pendaftaran yang ada pada Desain Industri hanya dengan menggunakan sistem pendaftaran konstitutif, berbeda dengan Hak Cipta yang menganut asas sistem pendaftaran deklaratif. Yang dimaksud dengan system pendaftaran konstitutif ialah suatu sistem yang mengatakan hak desain itu baru terbit setelah dilakukan pendaftaran yang telah mempunyai kekuatan. Sistem konstitutif ini

13 http://www.dqip.go.id/ebhtml/hki, 28 Juli 2016,13.30 WIB

${ }^{14}$ http://www.kennywiston.com, 28 Juli 2016,13.30 WIB untuk memperoleh hak tersebut tergantung pendaftarannya. ${ }^{15}$

Perlindungan desain mempunyai waktu yang berbeda satu sama lain disesuaikan landasan ketentuan yang mendasarinya. Di Inggris perlindungan terhadap suatu desain industri diberikan selam 5 tahun dan dapat diperpanjang dua kali masing - masing 5 tahun atau 15 tahun; atau dengan Undang - Undang baru menjadi 25 tahun. Di Austria, perlindungan Desain Industri hanya diberikan selama 3 tahun, di Perancis perlindungannya selama 50 tahun. Amerika Serikat perlindungannya selama 14 tahun, sedangkan di Indonesia perlindungan desain industri semula jangka waktunya hanya diberikan 5 tahun dan dapt diperpanjang satu kali untuk 5 tahun atau totalnya 10 tahun. Sesuai dengan Pasal 26 ayat (3) Persetujuan TRIPs, jangka waktu perlindungan desain industri diberikan untuk jangka waktu 10 tahun. Ketentuan ini dicantumkan dalam UU Desain Industri, bahwa perlindungan terhadap hak desain industri diberikan untuk jangka waktu sepuluh tahun terhitung sejak tanggal penerimaan. Tanggal mulai berlakunya jangka waktu perlindungan hukum dimaksud dicatat dalam Daftar Umum Desain Industri dan diumumkan dalam Berita Resmi Desain Industri. ${ }^{16}$

Selama jangka waktu tersebut, orang lain dilarang membuat, memakai, menjual, mengimpor dan / atau mengedarkan produk yang telah diberi Hak Desain Industri. Hak Desain Industri adalah hak khusus (exclusive right) yang diberikan oleh Negara Republik Indonesia kepada Pendesain atas hasil kreasinya, untuk selam waktu tertentu

15 Yuoky Surinda, Perlindungan Hukum Terhadap Pemegang Merek di Indonesia, Skripsi Fakultas Hukum UII, Yogyakarta, 2006 hlm 29. 16 Ibid. hlm 431 
Media Komunikasi dan Informasi Hukum dan Masyarakat

melaksanakan sendiri kreasi tersebut, atau memberikan persetujuannya kepada pihak lain untuk melaksanakannya.

Syarat Desain Industri yang mendapatkan perlindungan:

1. Memenuhi persyaratan substansi:

1.1. Kreasi Desain Industri yang memberikan kesan estetis (Ps.1 UU No. 31/2000). Kreasi bentuk, konfigurasi, komposisi garis dan warna atau kombinasinya yang memberikan kesan estetis. Kreasinya bukan semata-mata fungsi atau teknis ( Ps. 25 (1) perjanjian TRIPs);

1.2 Kreasi Desain Industri yang dapat dilihat dengan kasat mata. Lazimnya suatu kreasi Desain Industri harus dapat dilihat jelas dengan kasat mata (tanpa menggunakan alat bantu), dimana pola dan bentuknya jelas. Jadi kesan indah/estetisnya ditentukan melalui penglihatan bukan rasa, penciuman dan suara;

1.3 Kreasi Desain Industri yang dapat diterapkan pada produk industri \& kerajinan tangan (Ps.1 UU no. 31/2000). Dapat diproduksi secara massal melalui mesin maupun tangan. Jika diproduksi ulang memberikan hasil yang konsisten;

1.4 Kreasi Desain Industri yang baru (Ps.2 (1) UU No. 31/2000). Tidak sama dengan pengungkapan yang telah ada sebelum tanggal penerimaan atau tanggal prioritas (bila dg hak prioritas) dan telah diumumkan/digunakan baik di Indonesia atau di luar Indonesia (Ps. 2 (2) \& Ps. 2 (3) UU No.31/2000). Baru dinilai dari sudut kreasi dan/atau produknya. Nilai kemiripan, nilai kreatifitas, dan nilai karakter individu suatu desain industri tidak diatur dalam UU No.31/2000). Nilai baru/kebaruan maknanya nilai tidak identik atau berbeda atau tidak sama atau tidak identik dengan "pengungkapan" yang telah ada sebelumnya;

$1.5 \quad$ Kreasi Desain Industri yang
tidak bertentangan dengan peraturan
perundang-undangan yang berlaku, ketertiban umum, agama atau kesusilaan (Ps.4 UU no. 31/2000).

1.6 Memenuhi persyaratan administrasi/ formalitas (Ps. 11, 13, 14, 15, 16, 17 \& Ps.19 (1) UU no.31/2000) Tidak ditarik kembali permohonannya (karena memenuhi persyaratan permohonan - Ps. 20 (1) \& Pemohon tidak menarik permohonannyaPs.21 UU No.31/2000)

Agar permohonan pendaftaran desain industri anda dapat diberikan (granted) pastikan persyaratan di atas terpenuhi. Untuk mendapatkan nilai baru atau kebaruan cari perbedaan sebanyak-banyaknya terhadap desain yang telah ada sebelumnya.

\section{E. Peralihan Hak Atas Desain Industri}

Hak yang dimiliki oleh Pendesain atas desainnnya tersebut merupakan hak milik perseorangan yang tidak berwujud dan timbul karena kemampuan intelektual manusia. Dalam konsep hak kekayaan intelektual maka hak atas desain tersebut dapat dialihkan oleh desainer atau yang berhak atas desain tersebut. Pengalihan hak atas desain tersebut dapat dilakukan kepada perorangan atau badan hukum. Sesuai dengan Pasal 31 ayat (1) UU Desain Industri tahun 2000 cara pengalihan desain industri tersebut dapat melalui:

1. Pewarisan.

2. Hibah.

3. Wasiat.

4. Perjanjian tertulis; atau 
Media Komunikasi dan Informasi Hukum dan Masyarakat

5. Sebab- sebab lain yang dibenarkan oleh peraturan perundang-undangan.

Perlu diketahui jika pengalihan yang dimaksud pada butir a, b, dan c ketentuan yang belaku masih pluralisme, Hukum waris, hibah, dan wasiat belum ada yang berlaku secara unifikasi, masih berbeda untuk setiap golongan penduduk. Ada yang tunduk kepada hukum Islam, ada juga yang tunduk kepada hukum perdata yang termuat dalam KUH Perdata.

Pengalihan hak atas Desain Industri Terdaftar dengan perjanjian harus dituangkan dalam bentuk akta perjanjian. Pengalihan hak atas Desain Industri disertai dengan dokumendokumen pendukungnya antara lain sertifikat Desain Industri yang mendukung pemilikan hak tersebut. Pengalihan hak atas Desain Industri terdaftar wajib dimintakan pencatatan kepada Dirjen HAKI untuk dicatat dalam Daftar Umum Merek. Pengalihan yang telah tercatat tadi diumumkan dalam Berita Resmi Desain Industri. Pengaliahan melalui perjanjian pada prinsipnya menganut asa kebebasan berkontrak. Maka harus diperhatikan syarat-syarat yang harus dipenuhi untuk sahnya suatu perjanjian (Pasal 1320 KUH Perdata) dan syarat-syarat umum lainnya yang tercantum dalam Pasal $1319 \mathrm{KUH}$ Perdata.

Walaupun hak atas desain industri telah dialihkan, tetapi hak moralnya tetap melekat pada pendesainnya, dengan tidak menghilangkan hak pendesain untuk tetap dicantumkan namanya dan identitasnya, baik dalam Sertifikat Desain Industri, Berita Resmi Desain Industri maupun dalam Daftar Umum Desain Industri.

Hak desain industri juga dapat diberikan kepada orang lain melalui perjanjian lisensi. Dalam
Pasal 1 angka 11 UU Desain Industri disusun pengertian lisensi, yaitu:

Lisensi adalah izin yang diberikan oleh pemegang Hak Desain Industri kepada pihak lain melaui suatu perjanjian berdasarkan pada pemberian hak (bukan pengalihan hak) untuk menikmati manfaaat ekonomi dari suatu Desain Industri yang diberi perlindungan dalam jangka waktu tertentu dan syarat tertentu.

Perjanjian lisensi merupakan cara pemberian hak atas desain industri oleh pemegang hak desain industri kepada pihak lain. Dengan adanya perjanjian lisensi hak desain industri, penerimanya diizinkan untuk menikamati manfaat ekonomis yang ditimbulkan dari suatu desain industri yang dilisensikan tersebut. Izin tersebut diberikan untuk desain industri yang telah mendapatkan perlindungan. Pemegang Hak Desain Industri dapat memberikan hak ekslusif yang diberikan Negara untuk tetap dapat melaksanakan sendiri atau memberi lisensi kepada pihak ketiga untuk melaksanakan perbuatan atau melarang orang lain yang tanpa persetujuannya membuat, memakai, menjual, atau mengimpor, mengekspor dan /atau mengedarkan produk yang diberi Hak Desain Industri, kecuali jika diperjanjikan lain (Pasal 34 UU Desain Industri). Perjanjian lisensi dilarang memuat ketentuan, baik langsung maupaun tidak langsung dapat menimbulkan akibat yang merugikan perekonomian Indonesia atau memuat ketentuan yang mengakibatkan persaingan usaha tidak sehat. Ketentuan yang tercantum dalam Pasal 36 UU Desain Industri dimaksudkan untuk melindungi kepentingan Negara dari kemungkinan hal-hal buruk yang terjadi dari perjanjian lisensi tersebut. 
Media Komunikasi dan Informasi Hukum dan Masyarakat

\section{F. Pemeriksaan Desain Industri}

Pemeriksaan desain industri dimulai dengan pemeriksaan administrative permohonan pendaftaran desain industri. Dalam Pasal 34 UU Desain Industri dinyatakan bahwa Direktorat Jendral HAKI melakukan pemeriksaan administratif terhadap permohonan pendaftaran desain industri sesuai dengan ketentuan sebagaimana dimaksud dalam peraturan perundang- undangan yang berlaku. Pemeriksaan adminstratif (formality check) disini merupakan pemeriksaan yang berkaitan dengan kelengkapan persyaratan administratif permohonan sebagaimana yang dimaksud dalam Pasal 11 UU Desain Industri.

Direktorat Jendral HAKI akan memberitahukan keputusan penolakan permohonannya kepada pemohon apabila desain industri yang dimohonkan tidak dapat diberi perlindungan atau memberitahukan anggapan ditarik kembali permohonannya karena dianggap tidak memenuhi kekurangan persyaratan formalitas dan pemohon atau kuasanya diberikan kesempatan untuk mengajukan keberatan atas keputusan penolakan atau anggapan penarikan kembali dalam waktu paling lama 30 (tiga puluh) hari terhitung sejak tanggal diterimanya surat penolakan atau pemberitahuan penarikan kembali tersebut. Ini dimaksudkan untuk memberikan kesempatan kepada pihak yang mengajukan permohonan untuk memperbaiki desain industri tersebut, seandainya dengan menghilangkan bagian yang dianggap bertentangan dengan kesusilaan (Pasal 34 UU Desain Industri). Keputusan tersebut dinyatakan bersifat tetap bila pemohon atau kuasanya tidak mengajukan keberatan dalam tenggang waktu yang telah ditentukan.
Setelah semua persyaratan terpenuhi, permohonan desain industri akan diumumkan oleh Direktorat Jendral HAKI dengan cara menempatkannya pada sarana yang khusus untuk itu yang dapat dengan mudah serta jelas dilihat oleh masyarakat, paling lama 3 (tiga) bulan terhitung sejak tanggal penerimaan.

Pasal 25 ayat (2) UU Desain Industri menjelaskan bahwa pengumuman pendaftaran desain indsutri harus mencantumkan:

1. nama dan alamat lengkap pemohon;

2. nama dan alamat lengkap kuasa dalam hal permohonan diajukan melaui kuasa;

3. tanggal dan nomor penerimaan permohonan;

4. nama Negara dan tanggal penerimaan permohonan yang pertama kali apabila permohonan diajukan dengan menggunakan hak prioritas;

5. judul desain industri;

6. gambar atau foto desain industri.

Pada saat pengajuan permohonan, pemohon dapat meminta secara tertulis agar pengumuman permohonan ditangguhkan dengan ketentuan tidak boleh melebihi 12 (dua belas) bulan terhitung sejak tanggal penerimaan atau terhitung sejak tanggal prioritas. Ini dimaksudkan untuk memberikan kesempatan kepada pemohon yang menganggap perlu penangguhan pengumuman demi kepentingannya.

Sejak dimulainya pengumuman permohonan desain industri yang telah memenuhi formalitas, menurut Pasal 26 UU Desain Industri setiap pihak dapat mengajukan keberatan (oposisi) tertulis paling lama 3 (tiga) bulan terhitung sejak tanggal dimulainya pengumuman yang mencakup hal-hal yang bersifat substantif kepada Direktorat Jendral HAKI dangan membayar biaya.

Pemeriksaan substantif adalah pemeriksaan terhadap permohonan berdasarkan Pasal 2 dan Pasal 4 untuk 
Media Komunikasi dan Informasi Hukum dan Masyarakat

mengetahui aspek kebaruan yang dimohonkan, yang dapat dilakukan dengan menggunakan referensi yang ada. Pemeriksaan substantif dilakukan oleh "pemeriksa" yang merupakan tenaga ahli yang secara khusus dididik dan diangkat untuk melaksanakan tugas tersebut. Ketentuan ini dicantumkan dalam Pasal 27 UU Desain Industri.

Pasal 29 UU Desain Industri, bahwa dalam hal tidak terdapat keberatan hingga berakhirnya jangka waktu pengajuan keberatan, DIRJEN HAKI menerbitkan dan memberikan Sertifikat Desain Industri paling lama 30 (tiga puluh) hari terhitung sejak tanggal berakhirnya jangka waktu tersebut dan mulai berlaku terhitung sejak tanggal penerimaannya.

Namun sebaliknya menurut Pasal 28 UU Desain Industri, permohonan yang ditolak, pemohon atau kuasanya dapat mengajukan gugatan kepada Pengadilan Niaga dalam waktu paling lama 3 (tiga) bulan sejak tanggal pengiriman pemberitahuan keputusan penolakan permohonan pendaftaran desain industrinya. Dengan demikian, Pasal 28 UU Desain Industri, pemohon atau kuasanya masih diberikan kesempatan untuk mengajukan gugatan terhadap keputusan penolakan permohonan pendaftaran desain industri yang dianggap tidak sesuai dengan ketentuan Pasal 2 atau Pasal 4 UU Desain Industri. ${ }^{17}$

\section{G. Penutup}

Seorang pendesain mempunyai hak cipta atas hasil kreativitasnya yang berupa cetak biru dan mempunyai hak eksklusif untuk membuat karya seni itu menjadi tiga atau dua dimensi. Undang-undang desain industri diarahkan untuk melindungi barang-barang yang diproduk secara masal. Orang lebih memilih

\footnotetext{
${ }^{17}$ https://id.wikipedia.org/wiki/Desain_industri
}

perlindungan dengan hak atas desain industri, yang hanya dilindungi selama 10 tahun. Hal ini disebabkan suatu desain sangat mudah dan cepat ditiru oleh masyarakat umum. Bila dilindungi dengan hak cipta, menjadi tidak efektif dan mubasir. Hak cipta tidak melindungi produk masal.

\section{Daftar Bacaan}

\section{A. Buku}

Budi Agus Riswandi dan $M$. Syamsudin, Hak Kekayaan Intelektual dan Budaya Hukum, Ctk Pertama, Raja Grafindo Persada, Jakarta, $2004 \mathrm{hlm} 55$

John Heskett, Desain Indusri, Terjemahan Chandra Johan, Rajawali, Jakarta, 1986, hlm 5.

Muhammad Djumhamna, Aspek - Aspek Hukum Desain Industri di Indonesia, Citra Aditya Bakti Bandung, $1999 \mathrm{hlm} 1$.

Rizky A. Adiwilaga, Impelmantasi UU. No. 31 Tahun 2000, Disajikan dalam Pelatihan HAKI, LKBH UII, Yogyakarta, 2001, hlm 3.

Rachmadi Usman, Hukum Hak Atas Kekayaan Intelektual Perlindungan dan Dimensi Hukumnya di Indonesia, Bandung, 2003 hlm 425.

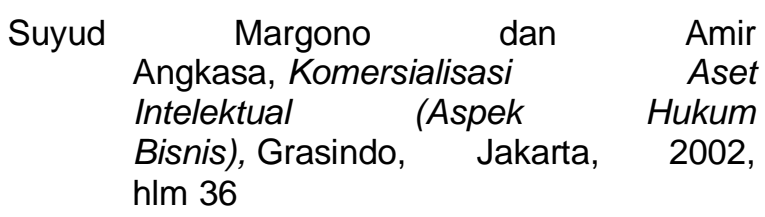

Yuoky Surinda, Perlindungan Hukum Terhadap Pemegang Merek di Indonesia, Skripsi Fakultas Hukum UII, Yogyakarta, 2006 hlm 29.

\section{B. Internet}

http://www.dgip.go.id/ebhtml/hki,28Juli

2016,13.30 WIB

http://www.kennywiston.com,28Juli $\quad 2016,13.30$ WIB

https://id.wikipedia.org/wiki/Desain industrihttps: //id.wikipedia.org/wiki/Desain industrihttp://ww w. Iprcentre.org/artikel, 28 Juli 2016,13.30 WIB 